DOI: 10.17707/AgricultForest.63.1.28

\begin{abstract}
Dušica RADONJIĆ, Božidarka MARKOVIĆ, Dragana DROBNJAK and Milan MARKOVIC ${ }^{I}$
\end{abstract}

\title{
LINEAR SCORING OF BROWN SWISS CATTLE BREED IN MONTENEGRO
}

\section{SUMMARY}

Brown cattle has become one of the globally most important breed for milk production. Many of its characteristics, such as longevity, production capacity, adaptability and fertility, have contributed to becoming a cosmopolitan breed. Also in Montenegro, Brown cattle breed takes very important place, especially in the northern part of the country where the largest number of animals of this breed is reared.

Linear scoring of brown cows was done in three areas: Pljevlja, Berane and Bijelo Polje. Results were analyzed separately for the first three lactations, while all subsequent lactations were treated together.

The linear scoring showed that certain type traits do not deviate much from the optimum (feet and legs), some characteristics deviate moderately (udder and some feet and legs traits) while there are those that have the largest deviation from the desired score (frame and rump).

The final linear score for all lactating cows places them in the category of very good. In terms of type traits Montenegrin Brown breed is not much inferior to European countries. Descriptive statistics for all traits was done. Statitical analysis showed significant differences between lactations for body measures (body depth, body lenght) but only for rear udder height an teat placement of all type traits $(\mathrm{P}<0.05)$.

Keywords: Brown Swiss, linear scoring, type traits.

\section{INTRODUCTION}

Cattle selection only on milk yield may adversely affect some properties, especially those which are of importance to the length of using cows. Therefore, it is very important that the selection criteria, in addition to milk production traits, include information on the type which will help in the selection of profitable long-lived cows.

To prolong productive life of cows for milk production special attention should be paid to the characteristics of the type and constitution. The disadvantages of type traits have leads to lower production, poor health and

Dušica Radonjić (corresponding author: dradonjić5@gmail.com), Božidarka Marković, Dragana Drobnjak and Milan Marković, University of Montenegro, Biotechnical faculty, Podgorica, MONTENEGRO

Notes: The authors declare that they have no conflicts of interest. Authorship Form signed online 
premature exclusion from the exploitation of cows (Casanova, 1993). Selection of the exterior has multiple purposes in the breeding programs. Mindful of the exterior of offspring greatly reduce the possibility of spreading undesirable properties (exterior faults, inherited diseases), which bulls can have as hidden (recessive), which due to the application of artificial insemination can rapidly spread in the population (Pantelić et al., 2005).

Phenotypic differences between the type traits and production characteristics are positive but relatively low, so the assessment of the exterior can not perform the selection in terms of production. Yonikovski and Todorov (2009) reported that improving most of the type traits increasing milk production, but on the other side traits of body frame have low heritability. Milk yield in the standard lactation, and milk yield in one milking are positively correlated with the distance between the fore and rear teats before milking (Tilki et al, 2005).

Wiggans et al (2006) showed that traits of legs and feet are in very poor correlation with production traits, but they are positively correlated with the ability of survival and functional life of the flock.

Many authors indicate that the udder is the most important part of the body of the dairy cow and its morphological and physiological characteristics affect health of cows (Gulyas and Ivancsics, 2002; Umzay et al., 2003; Weiss et al., 2004; Tancin et al., 2007). Berglund et al. (2007), Forsbäck et al. (2011), Haghkhah et al. (2011), De Jong (1997) also argue that development of the cow's udder quarters is very important for better milk production. Slyzius et al. (2014) approved correlation between mastitis appearance and udder characteristics. Length of production life of dairy cows is positively correlated with several production and linear type traits, and data from these correlated traits are available earlier in life and are more highly heritable than is production life (Weigel et al., 1998).

De Haas et al. (2007) indicate genetic correlations with production traits (milk, fat and protein yield) and type traits differed between the dairy breeds. Stronger correlations were found in Brown Swiss and Red \& White breed. Thurl width correlated positively with milk yield traits in Holstein and Red \& White, but negatively in Brown Swiss. Results shows that conformation traits can be used as predictors for various purposes in dairy cattle breeding, but require adaptation for each breed.

Linear scoring system does not qualify traits as good or bad. The traits are described from 1 to 9, which represent the biological extremes (Berry et al., 2004). All traits are classified into four groups which in proportion to the importance participating in the final score: body frame, rump, legs and feet (functionality) and udder. The largest share in the overall score take udder traits, as much as $40 \%$, the frame of body part as well as the feet and legs of $25 \%$ while the lowest part occupied the rump traits, only $10 \%$. Linear scoring method is gradually introduced into the breeding programs of all breeders associations of dairy cattle and combined cattle. 
Table 1: Linear traits

\begin{tabular}{|c|c|c|c|c|}
\hline \multirow{2}{*}{ GROUP } & \multirow{2}{*}{ Traits } & \multicolumn{2}{|c|}{ Share in total csore } & \multirow{2}{*}{$\begin{array}{c}\text { Optimum } \\
\text { (desired score) }\end{array}$} \\
\hline & & Tarits & Groupe & \\
\hline \multirow{4}{*}{ FRAME } & Stature & 5 & \multirow{4}{*}{$25 \%$} & $143-148$ \\
\hline & Chest width & 7 & & 8 \\
\hline & Body depth & 7 & & 8 \\
\hline & Topline & 6 & & 7 \\
\hline \multirow{4}{*}{ RUMP } & Rump lenght & 2 & \multirow{4}{*}{$10 \%$} & 8 \\
\hline & Rump position & 4 & & 5 \\
\hline & Thurl with & 2 & & 8 \\
\hline & Rump angle & 2 & & 7 \\
\hline \multirow{4}{*}{$\begin{array}{c}\text { FEET } \\
\text { AND } \\
\text { LEGS }\end{array}$} & Rear legs (side view) & 8 & \multirow{4}{*}{$25 \%$} & 5 \\
\hline & Bone structure & 4 & & 9 \\
\hline & Foot angle & 6 & & 6 \\
\hline & Foot height & 7 & & 8 \\
\hline \multirow{12}{*}{ UDDER } & Fore udder lenght & 3 & \multirow{12}{*}{$40 \%$} & 8 \\
\hline & Fore udder attachment & 4 & & 9 \\
\hline & Rear udder witdh & 3 & & 9 \\
\hline & Rear udder height & 4 & & 9 \\
\hline & Udder cleft & 4 & & 7 \\
\hline & Udder depth & 8 & & 7 \\
\hline & Udder balance & 4 & & 5 \\
\hline & Teat lenght & 2 & & 5 \\
\hline & Teat thickness & 1 & & 5 \\
\hline & Teat placement & 2 & & 5 \\
\hline & Fore teat placement & 3 & & 6 \\
\hline & Rear teat placement & 2 & & 5 \\
\hline
\end{tabular}

Swiss Brown cattle Breeders Association (1897-1997); Plesnicar (2010)

\section{MATERIAL AND METHODS}

Linear scoring was done according to the recommendations of the Swiss Brown cattle Breeders Association (1897-1997) and Plesnicar (2010). The scoring was done on farms in the municipalities of Pljevlja (5 farms), Berane (4 farms) and Bijelo Polje (4 farms) in the year 2011-2012. The survey included farms that have a tradition of breeding Brown breed and where grown animals that meet the standard of the breed.

Animals for which exist data for milk production were scored first, after that younger animals (the first, second and third lactation) and older animals at the end. We scored 16 cows in first lactation, 19 cows in second lactation, 21 cows in third lactation and 24 older cows, 80 cows were scored in total. For taking body measurements Lydtin stick and measuring tape were used. 
With Lydtin stick were measured:

-Stature

-Body depth

With tape were measured:

-Heart girth

-Body length

-Ramp length

-Ramp width

Traits scored from 1 to 9 :

-Topline

-Ramp angle

-Rear legs (back view)

-Rear legs (side view)

-Foot angle

-Foot height

-Fore udder attachment

-Fore udder length

-Rear udder height

-Udder cleft

-Udder depth

-Rear udder width

-Fore teat placement

-Teat length

-Teat thickness

-Rear teat placement

-Teat placement

-Udder balance

-Muscularity

-Dairy character.

Those results were analysed by lactation. Comparison with optimized scores was made and the average score for each lactation separately and the average score for this breed was calculated. The data were processed using the computer programme STATISTICA 12. Descriptive statistics was done and LSD test for testing statistical significance between lactations $(\mathrm{p} \leq 0.05)$.

\section{RESULTS AND DISCUSSION}

The average heart girth of cows in first lactation was $184.34 \mathrm{~cm}$ and the average body length $158 \mathrm{~cm}$. These physical measures were less for cows in first lactation compared with other lactations.

Comparative score for first lactation brown cows indicated by the Brown Swiss Cattle Federation (1897-1997), and first lacation cows in Montenegro is given in Graph 1. According to these data, it is evident that the Montenegrin cows in firs lactation is exterior lagging behind the European Brown breed. 
Rear teat placement

Fore teat placement

Teat placement

Teat thickness

Teat lenght

Udder balance

Udder depth

Udder cleft

Rear udder height

Rear udder witdh

Fore udder attachment

Fore udder lenght

Foot height

Foot angle

Bone structure

Rear legs (side view)

Rump angle

Thurl width

Rump length

Topline

Body lenght

Girth width

Hip height

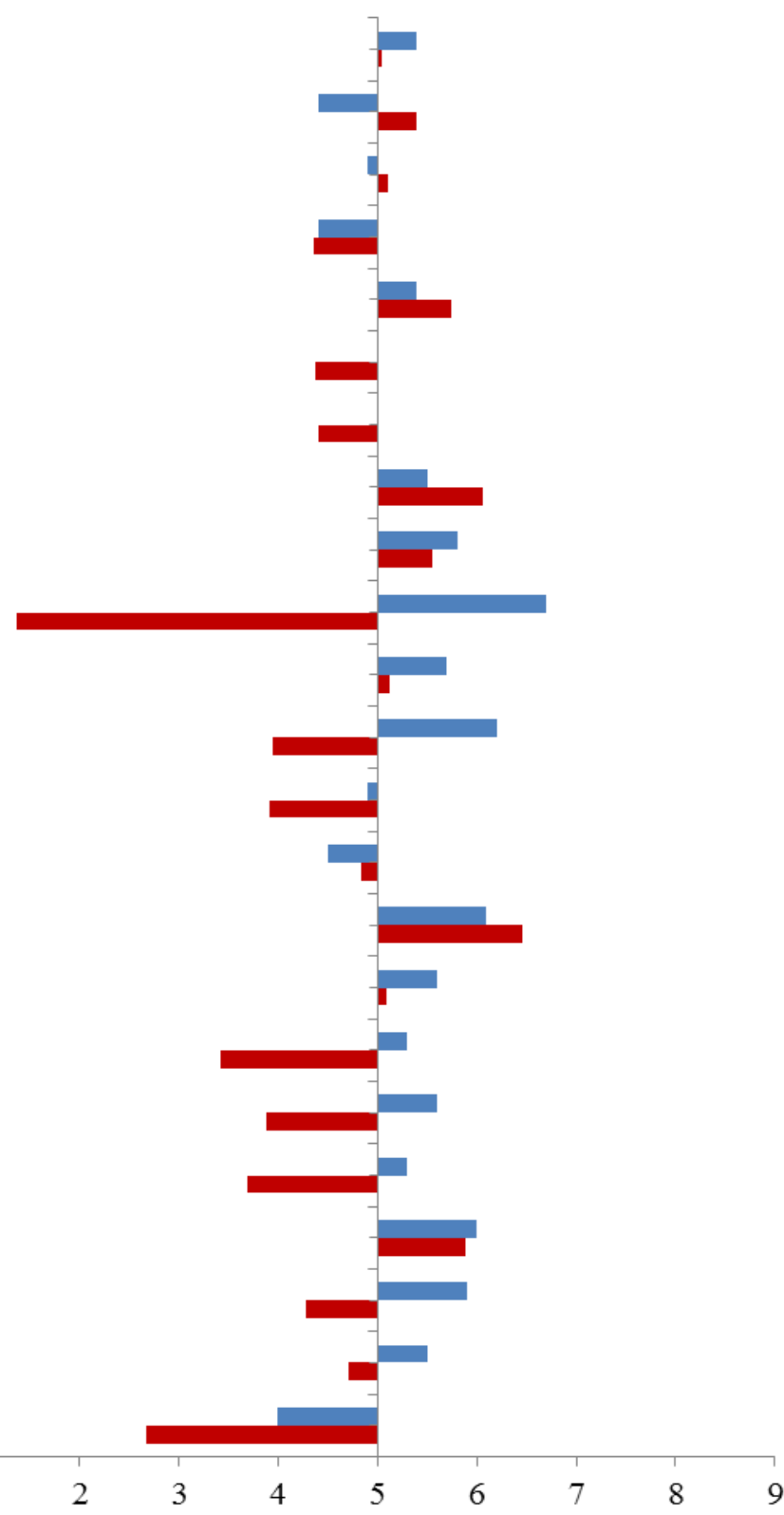

- First lactation European 1996. - $\quad$ First lactation Montenegrin brown breed

Graph1: Comparison scores of first lactation Montenegrin Brown breed and European first lactation 1996.

The greatest deviation has the ramp width, rump length, body depth. Udder traits has a slight difference, but at least deviating traits of legs and topline. 
All traits have a lot of variation (table 2). Muscularity of brawn cows in first lactation was evaluated with 5.5, and dairy character also. These scores are below desirable scores, for dairy character desirable score is 9 , and 7 for muscularity. Some traits are very close to the required score (foot angle, teat length, teat placement), while some traits has somewhat larger deviation (udder balance, fore teats placement, feet position).

Other traits more deviate from desirable score, some of them moderately (topline, suspensory ligament, udder depth, teat thickness, rear teat placement). The maximum deviation from the optimum demonstrated the traits: chest width, body depth, rump length, thurl width, rump angle, feet height, bone structure, fore udder lenght, fore udder attachment, some of them are almost opposite extremes (rear udder width).The final score is obtained by multiplying the scores for each trait, with the participation of the group of traits in the overall assessment. The final score of first lactation puts them in a group of very good cows on a scale up to 50 .

The average chest girth of the cows in the second lactation was $193 \mathrm{~cm}$ and the average body length $162 \mathrm{~cm}$. Muscularity of cows in second lactation was scored with 8 , a dairy character with 7 . Muscularity is near perfect score. Preferred scor for dairy character is 9 so this trait deviates slightly more.

Very close to the desired assessment were: teat length, teat placement, placement of the fore and rear teats, while some features had larger deviation (udder balance, feet position).

The maximum deviation from the optimum demonstrated: body depth, rump length, thurl width, rump angle, feet height, fore udder length, rump height and the fore udder atachment, and some of them are almost opposite extremes (rear udder width).

Cows in second lactation has a slightly heighter overall score, but they are still scored as very good.

The average heart girth of cows in the third lactation was $189.45 \mathrm{~cm}$ and the average body length $161.38 \mathrm{~cm}$. Muscularity of cows in the third lactation was evaluated with 5.14 and dairy character with 5.09. Very close to the desired assessment were: hock angle, teat length, fore teat placement, while some traits have larger deviation (udder balance, rear legs, udder cleft, teat thickness, teats placement, topline).

The maximum deviation from the optimum demonstrated: body depth, rump lenght, thurl width, rump angle, fore udder length and the fore udder attachment. Almost opposite extreme was the rear udder width. The cows in the third lactation had similar final score as cows in the first and second lactation.

The average heart girth of older cows was $193.9 \mathrm{~cm}$, and the average body length $161.25 \mathrm{~cm}$. Muscularity was assessed with 5.79 , a dairy character with 6.54. Bearing in mind the desirable score for these features, the deviation in these cows is quite large.

Close to the desired score were: rear legs, teat placement, teat thickness, while some traits had larger deviation (udder balance, fore teat placement, teat 
length, topline). Maximum deviation from the optimum demonstrated: rump length, thurl width, rump angle, fore udder attachment. In older cows, also maximum deviation occurs in the rear udder width. The heighest overall score had older animals, but it deviates slightly from the previous lactation. Table 2 shows the average scores for type traits for all lactations.

Table 2: Descriptive statistics of linear scores for Montenegrin Brown breed

\begin{tabular}{|l|c|c|c|c|c|c|}
\hline Traits & $\overline{\mathbf{X}}$ & SE & SD & CV & Min & Max \\
\hline Hip heightt, cm & 2,66 & 0,18 & 0,30 & 11,57 & 2,25 & 3,10 \\
\hline Girth width, cm & 4,71 & 0,46 & 0,78 & 16,70 & 3,85 & 6,00 \\
\hline Body lenght, cm & 4,28 & 0,37 & 0,63 & 14,92 & 3,18 & 4,75 \\
\hline Topline & 5,89 & 0,13 & 0,21 & 3,70 & 5,57 & 6,10 \\
\hline Rump lenght, cm & 3,69 & 0,20 & 0,33 & 9,18 & 3,18 & 4,14 \\
\hline Thurl width & 3,88 & 0,30 & 0,50 & 13,11 & 3,18 & 4,54 \\
\hline Rump angle & 3,41 & 0,04 & 0,06 & 1,92 & 3,31 & 3,50 \\
\hline Rear legs (side view) & 5,09 & 0,10 & 0,17 & 3,36 & 4,81 & 5,25 \\
\hline Bone structure & 6,45 & 0,15 & 0,26 & 4,03 & 6,15 & 6,87 \\
\hline Foot angle & 4,83 & 0,14 & 0,24 & 5,01 & 4,55 & 5,18 \\
\hline Foot height & 3,91 & 0,12 & 0,20 & 5,16 & 3,68 & 4,23 \\
\hline Fore udder lenght & 3,94 & 0,19 & 0,32 & 8,28 & 3,66 & 4,50 \\
\hline Fore udder attachment & 5,11 & 0,16 & 0,28 & 5,48 & 4,80 & 5,54 \\
\hline Rear udder witdh & 1,36 & 0,02 & 0,03 & 2,47 & 1,31 & 1,40 \\
\hline Rear udder height & 5,55 & 0,10 & 0,16 & 3,06 & 5,31 & 5,79 \\
\hline Udder cleft & 6,05 & 0,11 & 0,18 & 3,12 & 5,81 & 6,30 \\
\hline Udder depth & 4,40 & 0,58 & 1,01 & 22,94 & 3,00 & 5,75 \\
\hline Udder balance & 4,37 & 0,16 & 0,27 & 6,33 & 4,00 & 4,77 \\
\hline Teat lenght & 5,74 & 0,29 & 0,50 & 8,74 & 5,00 & 6,41 \\
\hline Teat thickness & 4,36 & 0,53 & 0,91 & 21,02 & 3,25 & 5,62 \\
\hline Teat placement & 5,10 & 0,12 & 0,20 & 4,03 & 4,8 & 5,31 \\
\hline Fore teat placement & 5,39 & 0,16 & 0,26 & 4,98 & 5,15 & 5,81 \\
\hline Rear teat placement & 5,04 & 0,10 & 0,13 & 3,30 & 4,93 & 5,33 \\
\hline
\end{tabular}

The average heart girth is $189.99 \mathrm{~cm}$, which is approximately equal for the Slovenian Brown breed, which, according to Spehar et al (2012), is $190.2 \mathrm{~cm}$. The average body length is $160.66 \mathrm{~cm}$.

Comparing those average scores with optimal scores for the Brown breed, it can be seen that the deviation from the optimum is different from single traits and groups. Similar scores fore udder traits found Mazza et al. (2013) in Valdostana cattle. Graph 2 shows comparative linear scoring of Brown breed in Montenegro and Slovenia. Most of the traits are quite different compared to the Slovenian Brown breed. Traits that deviate the most from the optimum differ from Slovenian scores. Rear udder deviates, then the feet height, fore udder length and rump angle. Teats placement, fore and back, heart gitrh and rear legs 
are rated similar as Slovenian Brown breed. For all traits statistical analysis were done.

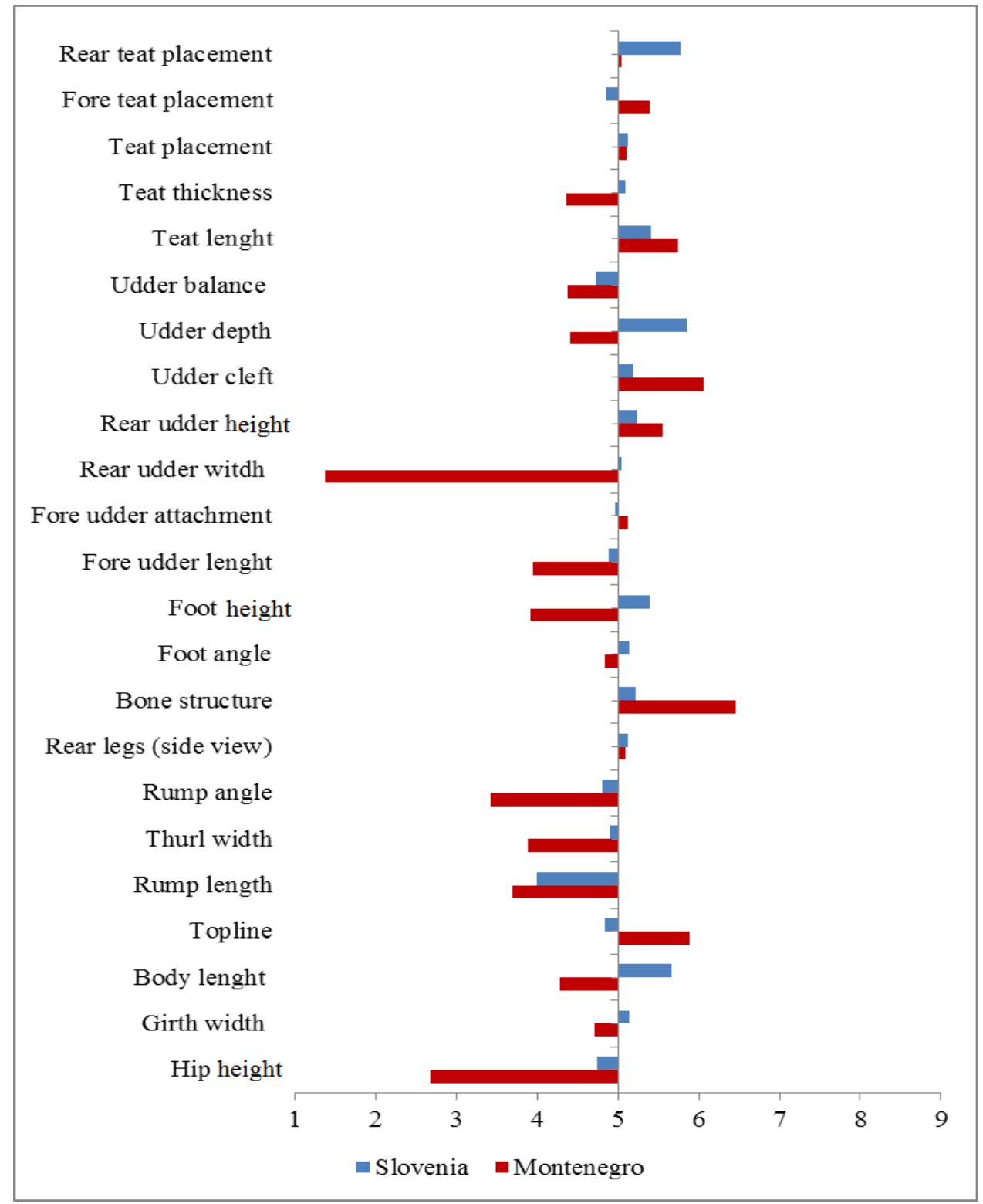

Graph 2: Comparative linear scoring of Brown breed in Montenegro and Slovenia

LSD test shows significant differences between different lactation groups for some body measures (body depth, rear udder height and body length) but only for rear udder height and teat placement of all type traits $(\mathrm{P}<0.05)$. For other linear traits statistically significant differences between lactations was not found. 
Table 3: LSD test for all traits

\begin{tabular}{|l|r|r|r|r|}
\hline \multicolumn{1}{|c|}{ Traits } & Sum of Squares & Mean Square & \multicolumn{1}{c|}{ F } & \multicolumn{1}{c|}{ Sig. } \\
\hline Stature & 8.055 & 2.685 & .849 & .472 \\
\hline Heart girth & 28.207 & 9.402 & 3.050 & .034 \\
\hline Body depth & 18.609 & 6.203 & 7.806 & $.000^{*}$ \\
\hline Topline & 3.997 & 1.332 & 1.422 & .243 \\
\hline Body length & 24.693 & 8.231 & 6.416 & $.001^{*}$ \\
\hline Ramp length & 8.299 & 2.766 & 2.854 & .043 \\
\hline Ramp width & .306 & .102 & .067 & .977 \\
\hline Topline & 2.079 & .693 & .591 & .623 \\
\hline Ramp angle & 4.643 & 1.548 & 1.755 & .163 \\
\hline Rear legs (back view) & 4.193 & 1.398 & .731 & .537 \\
\hline Rear legs (side view) & 3.152 & 1.051 & .463 & .709 \\
\hline Foot angle & 6.908 & 2.303 & 2.561 & .061 \\
\hline Foot height & 9.487 & 3.162 & 1.222 & .308 \\
\hline Fore udder attachment & 2.021 & .674 & .584 & .627 \\
\hline Fore udder length & .078 & .026 & .056 & .982 \\
\hline Rear udder height & 80.422 & 26.807 & 12.364 & $.000 *$ \\
\hline Udder cleft & 2.623 & .874 & .466 & .707 \\
\hline Udder depth & 3.165 & 1.055 & .702 & .554 \\
\hline Rear udder width & 6.305 & 2.102 & 1.348 & .265 \\
\hline Fore teat placement & 19.343 & 6.448 & 2.055 & .113 \\
\hline Teat length & 66.564 & 22.188 & 4.015 & .011 \\
\hline Teat thickness & 5.183 & 1.728 & 1.025 & .387 \\
\hline Rear teat placement & 2.039 & .680 & .390 & .760 \\
\hline Teat placement & 975.288 & 325.096 & 4.230 & $.008 *$ \\
\hline Udder balance & 183.821 & 61.274 & 1.000 & .398 \\
\hline Muscularity & 20.211 & 6.737 & 2.068 & .111 \\
\hline Dairy character & & & & \\
\hline Signicicant & & 1.705 & .173 \\
\hline
\end{tabular}

*Significant differencies

\section{CONCLUSIONS}

Linear scoring of first lactation cows was closest to the required scores. Leg traits a little more deviate from the desired scores. Moderate deviation showed a part of the udder traits and topline. Frame and rump trait had a maximum deviation from the optimum, as well as some leg traits. The final linear 
score for the first lactation is very good. Cows in second lactation have similar linear scores as first lactation cows. Udder traits had at least deviate from optimum, with the exception of the rear udder width. Legs traits a little more deviate from the desired scores. Frame and rump traits had maximum deviation from the optimum, as well as some leg traits. The final linear score is very good.

Linear scoreing cows in the third lactation was found at least deviation some udder and legs traits. Most legs traits was a little further from the desired scores. Rump traits hase a moderate deviation from the optimum. Maximum deviation has frame traits, as well as part of the udder traits. Cows in the third lactation also had a very good final score.

Linear score for the older cows is not much different than the younger ones. Closest to the desired traits were udder traits. Legs traits a little more deviate from the desired score. Moderate deviation had some traits of the udder and topline. Frame and rump traits had maximum deviation from the optimum, as well as some legs traits. Older cows have a very good final score, as well as all previous lactations.

Comparing the average linear score for individual traits with optimum, it can be seen that traits had various deviations. Based on these results it can be concluded that part of the legs traits and some udder traits were closest to the desired score. Moderate deviate some udder traits, topline and leg traits. Furthest from the optimal score were frame and rump traits.

Statitical analysis showed significant differences between lactations for body measures (body depth, body lenght) but only rear udder height and teat placement of all type traits $(\mathrm{P}<0.05)$.

\section{REFERENCES}

American Brown Swiss Federation: Description of linear type traits

Bach, A. and Busto, I. (2005): Effects on milk yield of milking interval regularity and teat cup attachment failures with robotic milking systems. Journal of Dairy Research, 72: 101-106.

Berglund, I., Pettersson, G., Östensson K. and Svennersten Sjaunja K. (2007): Quarter Milking for Improved Detection of Increased SCC. Reprod. Dom. Anim., 42: $427-$ 432

Berry, D.P., Buckley. F., Dillon, P. Evans, R.D. and Veerkamp, R.F. (2004): Genetic relationships among linear type traits, milk yield, body weight, fertility and soatic cell count in primiparous dairy cows. Irish Journal of Agricultural and Food Research 43: 161-176.

Casanova, L. (1993): Genetic evaluation of linear type traits for Swiss Braunvieh. Bull. No. 8. INTERBULL. Uppsala, Sweden.

De Haas, Y., Janss, L.L.G., Kadarmideen H.N.(2007): Genetic and phenotypic parameters for conformation and yield traits in three Swiss dairy cattle breeds. Animal breedeng and genetics, Volume 124, 12-19.De Jong, G. (1997): Scoring legs \& feet in the Dutch conformation scoring system. Interbull Bull 15, 130-135

Forsbäck, L., H. Lindmark-Mansson, K. Svennersten-Sjaunja, L. Bach Larsen and Andrén, A. (2011): Effect of storage and separation of milk at udder quarter level 
on milk composition, proteolysis, and coagulation properties in relation to somatic cell count. J. Dairy Sci., 94: 5341-5349.

Gulyas, L. and Ivancsics, J. (2002): Relationship between the somatic cell count and certain udder-morphologic traits. Acta Vet. Hung., 50: 373-383.

Haghkhah, M., Ahmadi, M. R., Gheisari, H. R. and Kadivar, A. (2011): Preliminary bacterial study on subclinical mastitis and teat condition in dairy herds around Shiraz. Turk. J. Vet. Anim. Sci., 35: 387-394.

Mazza, S., Sartori. C., Berry, D., Mantovani, R. (2013): Factors affecting linear type traits of Valdostana cattle. Agriculturae Conspectus Scientifi cus . Vol. 78, No. 3 (207211).

Plesnicar Pavla (2010): Ocenjevanje goved za rjavo pasmo goveda, Kmetijsko gozdarska zbornica Slovenije, KGZS- Zavod Nova Gorica.

Slyzius, E., Juozaitiene, V., Juozaitis, A., Zilaitis, V., Slyziene, B. and Cereskiene, E. (2014): udder quarters morphological and milking traits risk factors influencing productivity and subclinical mastitis in dairy cows. Bulgarian Journal of Agricultural Science, 20 (No 6), 1502-1507.

STATSOFT, STATISTICA 12 (2012): Copyright (C) StatSoft. http://www.statsoft.com/

Tancin, V., Ipema, B., Hogewerf, P. and Macuhova, J. (2006): Sources of variation in milk flow characteristics at udder and quarter levels. J. Dairy Sci., 89: 978-988.

Tilki, M., Inal, S., Colak, M., Garip, M. (2005): Relationships Between Milk Yield and Udder Measurements in Brown Swiss Cows. Turk J Vet Anim Sci 29, 75-81.

Yonikovski, M., Todorov, M. (2009): Evaluation of phenotypic and genetic parameters related to classification by type and productivity of cows of the dairy population in Bulgaria. Biotechnology in Animal Husbandry 25 (5-6), p 605-612.

Uzmay, C., Kaya, Y., Akbas Y. and Kaya, A. (2003): Effects of udder and teat morphology, parity and lactation stage on subclinical mastitis in Holstein cows. Turk. J. Vet. Anim. Sci., 27: 935-941.

Wiggans, R. (2006): Parameters and Evaluation of Rear Legs (Rear View) for Brown Swiss and Guernseys GAnimal Science Unit, Gembloux Agricultural University, B-5030 Gembloux, Belgium

Weiss, D., Weinfurtner, M. and Bruckmaier, R. M. (2004): Teat anatomy and its relationship with quarter and udder milk flow characteristics in dairy cows. J. Dairy Sci., 87: 3280-3289.

Weigel, K. A., Lawlor, JR. T. J. Vanraden, P. M. and Wiggans, G. R. (1998): Use of Linear Type and Production Data to Supplement Early Predicted Transmitting Abilities for Productive Life. J Dairy Sci 81:2040-2044. 